\title{
Collaborating to innovate: Effects on customer knowledge management and performance ${ }^{\grave{2}}$
}

\author{
Pilar Fidel ${ }^{\mathrm{a}, *}$, Walesska Schlesinger ${ }^{\mathrm{a}}$, Amparo Cervera ${ }^{\mathrm{b}}$ \\ a University of Valencia, Faculty of Economics, Department of marketing and market research, Av. Tarongers s/n 46022, Valencia, Spain \\ b University of Valencia, Faculty of Economics, International Economics Institute, Av. Tarongers s/n 46022, Valencia, Spain
}

\section{A R T I C L E I N F O}

\section{Article history:}

Received February 2014

Received in revised form October 2014

Accepted January 2015

Available online xxxx

\section{Keywords:}

Customer knowledge management

Innovation orientation

Customer collaboration

Marketing results

Innovation process

\begin{abstract}
A B S T R A C T
Scholars regard customer knowledge management (CKM) as a strategic resource for businesses to improve innovation, facilitate the detection of new market opportunities, and support long-term customer relationship management. However, literature suffers from a lack of understanding of customer collaboration's role in the innovation process and innovation orientation in CKM. Accordingly, this paper tests a model examining how both variables act as antecedents of CKM. The model also explores CKM and customer collaboration's effect on marketing results. Findings have important academic and managerial implications, and show that collaboration with customers and openness to innovation are key inputs because of their effects on CKM and marketing results. (c) 2015 Elsevier Inc. All rights reserved.
\end{abstract}

\section{Introduction}

SMEs are the backbone of Europe's economy, representing around 99\% of all European companies and account for two thirds of private sector jobs (European Commission, 2013). Although European economies gradually recover in 2011, companies in OECD countries still cope with recession, with a lack of financial support, and with a fierce labor cost competition in shrinking domestic markets (OECD, 2011). Innovation is a key driver of modern firms' growth and development. Innovation enables organizations adapt to changing environments to increase business efficiency. Companies investing in knowledge and innovation management will more likely survive and improve their performance while maintaining their competitive advantage (Pil \& Holwelg, 2003). Eisenhardt and Martin (2000) identify knowledge as the most important strategic resource for building sustainable competitive advantage. This approach is consistent with the service-dominant logic (SDL) framework. Lusch, Vargo, and O'Brien (2007) define knowledge as the basis for sustainable development of competitive advantage, by arguing that innovation capacity and competitiveness require knowledge (Nonaka \& Takeuchi, 1995). Knowledge and innovation are thus inseparable (Prahalad \& Ramaswamy, 2004).

\footnotetext{
The authors thank to the Cátedra Ciudad de Valencia 2013, InnDEA Foundation of the Valencian Local Government, and the University of Valencia for their research funding.

* Corresponding author.

E-mail addresses: pilar.fidel@uv.es (P. Fidel), m.walesska.schlesinger@uv.es (W. Schlesinger), amparo.cervera@uv.es (A. Cervera).
}

Sharing knowledge through collaborative innovation is increasingly important. Much research demonstrates that knowledge management implementation enhances successful innovation activities (Alegre, Sengupta, \& Lapiedra, 2011; Nesta \& Saviotti, 2005). SDL researchers increasingly highlight customer collaboration in service provision and innovation (Vargo \& Lusch, 2004). Customer collaboration allows organizations to learn, to meet customer demands, and to improve performance (Prahalad \& Ramaswamy, 2004).

This research increases literature's value by combining three isolated theories (the resource-based theory for innovation orientation, SDL theory for customer collaboration, and organizational learning theory for (KM). These theories provide a framework for testing a model gaining insight on the effect of customer collaboration, innovation orientation, and CKM on marketing results. This research also empirically tests proposition 2 by Lusch et al. (2007, p. 8) that "collaborative competence is a primary determinant of a firm's acquiring the knowledge for competitive advantage" regarding customers' contribution in the innovation co-creation process.

\section{Conceptual framework and hypotheses}

According to the SDL approach, collaborative competence allows including customers and other external stakeholders such as business partners in the innovation process, and using them to foster change (Lusch et al., 2007). Customer collaboration in the innovation process refers to "information and feedback on specific issues" and "extensive consultation with users by means of interviews, focus group and team discussion" (Alam, 2002, p. 255). 
Hurley and Hult (1998) define innovation orientation as a corporate culture actively seeking its members to innovate by encouraging them to create, contribute, and experiment new ideas at work.

Knowledge management comprises those organizational practices and dynamic capabilities in relation to (respectively) knowledge creation, preservation, and transfer. According to Alavi and Leidner (2001), knowledge management practices dimension results from knowledge application. This dimension consists of knowledge management systems, local abilities, and know-how. Implementing these components of knowledge management allows companies to perform several activities. Knowledge creation mainly affects the dynamic capabilities within knowledge management dimension. Cantner, Joel, and Schmidt (2009) empirically confirm the relationship between innovation orientation and knowledge management.

H1. Innovation orientation affects customer knowledge management directly and positively.

Lusch et al. (2007) posit that collaborative competence highly determines a firm's ability to acquire the knowledge for a competitive advantage. Fang, Palmatier, and Evans (2008) demonstrate that customer participation in a new product development positively affects information sharing and coordination effectiveness.

H2. Customer collaboration in the innovation process affects customer knowledge management directly and positively.

Vorhies and Morgan (2005) state that marketing results (or market efficiency) measure the degree to which companies achieve business objectives in relation to markets. Measures comprise market share, sales revenues, customer acquisition, and customer retention. Some studies, such as that of Santos, González, and Lopez (2013), empirically show that customer participation positively affects customer outcomes such as loyalty, customer satisfaction, and added value, and, consequently, affects business results like sales and market share. Ballantyne, Varey, Frow, and Payne (2008), and Vargo and Lusch (2004) indicate that customer collaboration positively affects business results.

H3. Customer collaboration in the innovation process affects marketing results directly and positively.

Finally, numerous studies (Massey, Montoya-Weiss, \& O'Driscoll, 2002; Zack, McKeen, \& Singh, 2009) report a positive relationship between knowledge management and organizational performance. Economists also demonstrate a positive relationship between knowledge management and financial results such as sales, market share, and profitability (Chadam \& Pastuszak, 2005; Huang \& Shih, 2009).

H4. Customer knowledge management in the innovation process affects marketing results directly and positively.

According to the previous discussion, Fig. 1 displays the research model.

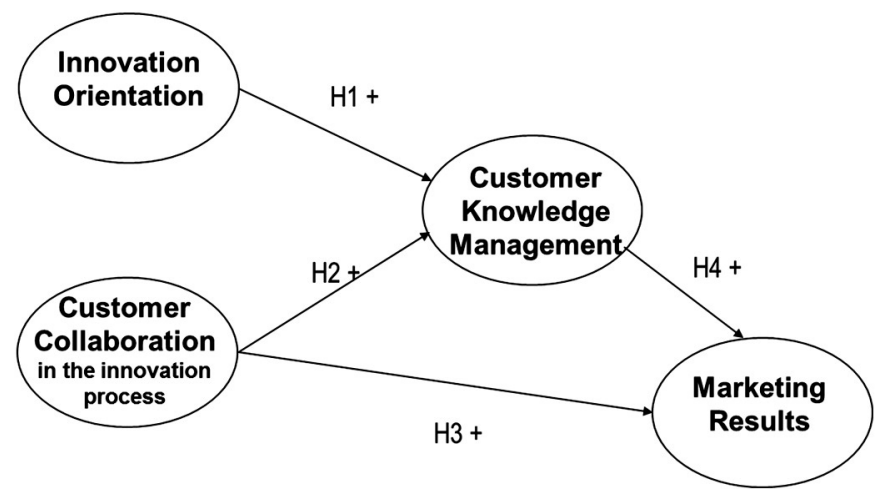

Fig. 1. Proposed model.

\section{Methodology and data analysis}

A survey to 210 companies in Valencia (Spain) provides the sample data. Valencia is the third largest city in Spain after Madrid and Barcelona. Before the quantitative phase, a dynamic group with eight representatives of the major business associations in Valencia helped verifying and refining relevant variables arising from literature review. This process provided the adapted variables for the questionnaire. According to this preliminary qualitative information and company owners being key informants, data collection took place using random stratified probability sampling with proportional allocation to main economic sectors to ensure the representativeness of the population under study. Personal interviews responded to a standard questionnaire.

Most companies in the sample (96\%) have fewer than 20 employees, and $60 \%$ of the companies are more than six years old. In $81.5 \%$ of the companies, managers or owners are older than 35 years, and $69.5 \%$ of the managers or owners have a basic to medium training level. The resulting sample pictures the population under study.

Customer collaboration measurement uses Ordanini and Parasuraman's (2011) scale. Innovation orientation assessment follows Santos and Álvarez's (2007) scale. The CKM measurement instrument adapts Alegre et al.'s (2011)scale, whereas marketing results measurement uses Vorhies and Morgan's (2005) scale. The measurement of all constructs uses a five-item Likert scale ( $1=$ completely disagree; to $5=$ completely agree).

To test the research model, this study uses the partial least square (PLS) technique, a variance-based structural equation modeling (SEM) method. This study uses the SmartPLS software (Ringle, Wende, \& Will, 2005) simultaneously for the measurement model and the structural model analysis.

\section{Results}

Results confirm constructs' high internal consistencies. Cronbach's alpha (higher than 0.9 for all measures) verifies validity. Bagozzi and Yi's (1988) composite reliability index (all values higher than 0.8), and Fornell and Larcker's (1981) average variance extracted index (higher than 0.7 for all measures) yield positive results.

All items load on their hypothesized factors, and estimates are positive and significant. The $\mathrm{R}^{2}$ measure for all the dependent factors is above 0.1, critical level for Falk and Miller (1992). Values for the $Q^{2}$ measure illustrate the model's sufficient predictive ability (above 0 in all cases).

Outcomes emphasize the relationships between customer collaboration, CKM, and marketing results. Results show that customer collaboration directly affects marketing results $(H 3: \beta=0.098 ; p<0.05)$, with a less intense relation than that $\mathrm{CKM}$ has with marketing results (H4: $\beta=0.405 ; p<0.001)$. Data analysis also demonstrates that, through CKM, customer collaboration indirectly affects marketing results. Finally, results indicate that customer collaboration is a more influential antecedent of CKM $(\mathrm{H} 2: \beta=0.349 ; \mathrm{p}<0.001)$ than innovation orientation is (H1: $\beta=0.101 ; \mathrm{p}<0.05)$. Table 1 contains these results.

Table 1

Structural modeling results.

\begin{tabular}{llll}
\hline Hypothesis & Support & $\begin{array}{l}\beta \text { path } \\
\text { coefficients }\end{array}$ & $\begin{array}{l}\text { t-Value } \\
\text { bootstrap }\end{array}$ \\
\hline H1: innovation orientation $\rightarrow$ CKM & Yes & $0.101^{* *}$ & 2.219 \\
H2: customer collaboration $\rightarrow$ CKM & Yes & $0.349^{*}$ & 6.821 \\
H3: customer collaboration $\rightarrow$ marketing results & Yes & $0.098^{* *}$ & 2.006 \\
H4: CKM $\rightarrow$ marketing results & Yes & $0.405^{*}$ & 7.98 \\
\hline
\end{tabular}

$\mathrm{R}^{2}(\mathrm{CKM})=0.1571 ; \mathrm{R}^{2}$ (marketing results) $=0.2044$.

$\mathrm{Q}^{2}(\mathrm{CKM})=0.0972 ; \mathrm{Q}^{2}$ (marketing results) $=0.0221$.

* $\mathrm{p}<0.001$

** $\mathrm{p}<0.05$. 


\section{Conclusions and managerial implications}

This research explores the effects of customer collaboration and innovation orientation on CKM and marketing results.

CKM becomes an important strategic resource that positively improves marketing results (Huang \& Shih, 2009). Results also show that CKM has a greater effect than innovation orientation does on improving marketing results. These factors positively improve marketing results, with CKM being the most important factor. Besides efficiently developing knowledge management systems, organizations need a culture to generate the ideas stimulating innovation and promoting CKM.

Findings yield several implications for business managers. This research demonstrates the need of consistent CKM implementation in SMEs. Firms with adequate CKM policies will more likely detect emerging market opportunities than their competitors will. A medium level of CKM in the sample (average of 3.3 in a scale from 1 to 5 ) highlights the need to implement effective CKM in companies (for example, market research activities). Results emphasize collaborating with customers within the innovation process. Results also reveal the importance of a culture open to innovation. Customer collaboration and openness to innovation are key inputs to CKM because they affect CKM and marketing results. Working with these key inputs companies may improve CKM and consequently their performance, maintaining their competitive advantage.

\section{References}

Alam, I. (2002). An exploratory investigation of user involvement in new service development. Journal of the Academy of Marketing Science, 30(3), 250-261.

Alavi, M., \& Leidner, D. (2001). Knowledge management and knowledge management systems: Conceptual foundations and research issues. MIS Quarterly, 25, 107-133.

Alegre, J., Sengupta, K., \& Lapiedra, R. (2011). Knowledge management and the innovation performance in a high-tech SMEs industry. International Small Business Journal, 31(4), 454-470.

Bagozzi, R., \& Yi, Y. (1988). On the evaluation of structural equation models. Journal of the Academy of Marketing Science, 16(1), 74-94.

Ballantyne, D., Varey, R., Frow, P., \& Payne, A. (2008). Service-dominant logic and value propositions: Re-examining our mental models. Otago Forum 2 - Academic Papers. New Zealand: Otago.

Cantner, U., Joel, K., \& Schmidt, T. (2009). The use of knowledge management by German innovators. Journal of Knowledge Management, 13(4), 187-203.

Chadam, J., \& Pastuszak, Z. (2005). Marketing aspects of knowledge-based management in groups of companies, case of Poland. Industrial Management E Data Systems, 105(4), 459-475.
Eisenhardt, K., \& Martin, J. (2000). Dynamic capabilities: What are they? Strategic Management Journal, 21, 1105-1122.

European Commission (2013). One trillion euro to invest in Europe's future - The EU's budget framework 2014-2020.

Falk, R., \& Miller, N. (1992). A primer for soft modeling. Akron, O.H.: University of Akron Press.

Fang, E., Palmatier, R., \& Evans, K. (2008). Influence of customer participation on creating and sharing of new product value. Journal of the Academy of Marketing Science, 36, 322-336.

Fornell, C., \& Larcker, D. (1981). Evaluating structural equation models with unobservable variables and measurement error. Journal of Marketing Research, 18(1), 39-50.

Huang, P., \& Shih, L. (2009). Effective environmental management through environmental knowledge management. International Journal of Environmental Science and Technology, 6(1), 35-50.

Hurley, R., \& Hult, G.T. (1998). Innovation, market orientation and organization learning: An integration and empirical examination. Journal of Marketing, 62(3), 42-54.

Lusch, R., Vargo, S., \& O'Brien, M. (2007). Competing through service: Insights from service-dominant logic. Journal of Retailing, 83(1), 5-18.

Massey, A., Montoya-Weiss, M., \& O'Driscoll, T. (2002). Knowledge management in pursuit of performance: Insights from Nortel Networks. MIS Quarterly, 26(3), 269-289.

Nesta, L., \& Saviotti, P. (2005). Coherence of the knowledge base and the firm's innovative performance: Evidence from the U.S. pharmaceutical industry. The Journal of Industrial Economics, 53(1), 123-142.

Nonaka, I., \& Takeuchi, H. (1995). The knowledge-creating company: How Japanese companies create the dynamics of innovation. New York, NY: Oxford University Press.

Ordanini, A., \& Parasuraman, A. (2011). Service innovation viewed through a servicedominant logic lens: A conceptual framework and empirical analysis. Journal of Services Research, 14(1), 3-23.

Organisation for Economic Co-operation and Development (2011). Timely indicators of entrepreneurship. Online consultation March 2013. Retrieved from: http://www. oecd.org/std/startpratesbegintoshowsignsofslowdowninmostoecdcountriesin2011. html

Pil, F., \& Holwelg, M. (2003). The advantages of thinking small. MIT Sloan Management Review, 33-39.

Prahalad, C., \& Ramaswamy, V. (2004). The future of competition: Co-creating unique value with customers. Boston: Harvard Business School Press.

Ringle, C., Wende, S., \& Will, A. (2005). SmartPLS 2.0 (M3) beta software. (Hamburg). http://www.smartpls.de.

Santos, M., \& Álvarez, L. (2007). Innovativeness and organizational innovation in total quality oriented firms: the moderating role of market turbulence. Technovation, 27, 514-532.

Santos, M., González, C., \& Lopez, J. (2013). An assessment of innovativeness in KIBS: Implications on KIBS'co-creation culture, innovation capability, and performance. Journal of Business E' Industrial Marketing, 28(2), 86-102.

Vargo, S., \& Lusch, R. (2004). Evolving to a new dominant logic for marketing. Journal of Marketing, 68, 1-17.

Vorhies, D., \& Morgan, N. (2005). Benchmarking marketing capabilities for sustained competitive advantage. Journal of Marketing, 69(1), 80-94.

Zack, M., McKeen, J., \& Singh, S. (2009). Knowledge management and organizational performance: An exploratory analysis. Journal of Knowledge Management, 13(6), 392-409. 